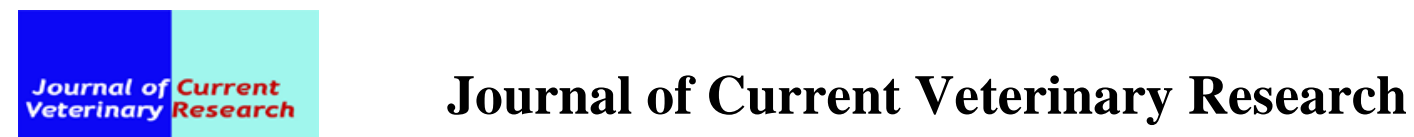

ISSN : 2636-4026

Journal homepage:http://www.jcvr.journals.ekb.eg

Parasitology

\title{
Studies on Ovine Coccidiosis in Menoof District, Menoufia, Egypt
}

\author{
Ahmed Elkhatam ${ }^{1}$, Mona El- Debakhy ${ }^{1}$, Mahmoud AbouLaila ${ }^{2}$, Nasr Elbahy ${ }^{1}$
}

(1) Department of Parasitology, Faculty of Veterinary Medicine, University of Sadat City, 32897, Menoufia, Egypt

(2) Department of Parasitology, Faculty of Veterinary Medicine, Damanhour University, Egypt.

*corresponding author: elkhtama@yahoo.comReceived: 2/9/2020Ａccepted: 25/9/2020

\begin{abstract}
Ovine coccidiosis is an enteric protozoal disease caused by obligatory intracellular Eimeria spp. (Family: Eimeridae) and cause severe economic losses in sheep industry. The present studywas conducted in Menoof district, Menoufia, Egypt from January to December 2019 to determine the prevalence of sheep coccidiosis and to identify the recovered Eimeria spp. Faeces of 610 randomly selected sheep were collected directly from rectum and subjected to parasitological examination (floatation technique). The results revealed that Eimeria spp. were detected in 33.3 $\%$ (203 out of 610). The prevalence was significantly influenced by season, age and sex of the examined sheep. Six Eimeria species were identified: Eimeria parva 78 (38.4\%), Eimeria ahasta 30 (14.8\%), Eimeria granulosa 29 (14.3\%), Eimeria pallida 43 (21.2\%), Eimeria fauri 10 (4.9\%) and Eimeria crandalis 13 (6.4\%). This is the first report of ovine coccidiosis in Menoufia, Egypt. Further studies as molecular diagnosis is required to easily discriminate different Eimeria species infecting sheep.
\end{abstract}

Keywords: Eimeria species, Epidemiology, floatation technique, Prevalence

\section{INTRODUCTION}

Ovine coccidiosis is a serious economic disease (Chartiera and Paraud 2012), caused by genus Eimeria in the intestines (small and large) of animals and affects mainly on small ages (Taylor and Catchpole, 1994; Platzer et al., 2005; Khan et al., 2011; Chartiera and Paraud 2012).

In Egypt, the incidence of ovine coccidiosis was reported in different localities, for example, in kaloubia (El-Akabawy, 1993 and Boshra, 1994), in Sharkia (Nasr et al., 2008), in Red sea (Mahran, 2009), in Sinai (Abouzeid et al., 2010), in Behera province (Bkheet et al., (2010), in Kafr-Elsheikh (Sultan et al., 2016), in Assuit (Mahmoud et al., 2018), in Suez (Mohamaden et al., 2018) and in Dakahlia (ElAlfy et al., 2020).

Coccidiosis in sheep may be clinical or subclinical (Lagares, 2008). Clinical coccidiosis determined by presence of diarrhea which can be bloody in adult animals (Foreyt,
1990) while in lambs and kids characterized by watery diarrhea, mucous in the form of clumps and may be changes in the feacal matter color to brown or yellow (Koudela and Bokiva, 1998), results in severe economic losses for producers because of medical treatment costs, adverse effect on performance, growth and sometimes lamb mortalities (Reeg et al., 2005; and Elmadawy and Elkhaiat, 2014). The subclinical coccidiosis causes intestinal function impairment, which decrease the animal's growth (Deniz, 2009) and lowers its performance (Taylor et al., 2011).

In sheep, coccidiosis causes high economic losses in Egypt (Gadelhaq et al., 2015) and different parts of the world due to its high prevalence (Levine 1985; Bakunzi et al., 2010 and Majeed et al., 2015), decreased productivity, low growth and costs of treatment. (Kaya, 2004). 
Eimeria spp. are host specific (McDougald, 1979), single or mixed infection may occur, of them, E. crandallis and E. ovinoidalis are highly pathogenic (Gregory et al. 1989). Several Eimeria species as Eimeria ahsata, Eimeria crandallis, Eimeria bakuensis, Eimeria granulosa, Eimeria faurei, Eimeria marsica, Eimeria parva, Eimeria pallida, Eimeria intricata, Eimeria ovinoidalis and Eimeria webybridgensis were identified and reported in Egypt.(El-Alfy et al., 2020).There is no previous study on ovine coccidiosis in Menoufia province; therefore, we conducted this study to determine the prevalence of ovine coccidiosis in Menoufia governorate, Egypt and its associated risk factors.

\section{MATERIALS AND METHODS}

\section{Study period and area}

The study was carried out all over one year extended from January to December 2019 at different four localities of Menoof district (Gizi, Tamali, Sinsaft and Barhim), Menoufia governorate, Egypt to determine the prevalence of Eimeria spp. infecting sheep.

\section{Animal samples}

A total number of 610 of feacal samples were collected directly from rectum of the examined sheep, once weekly from the examined locality and transported as soon as possible to Parasitology Lab, Faculty of Veterinary Medicine, University of Sadat City, Menoufia, Egypt. The examined sheep were divided into 4 groups according their age by months: Group 1 (<6months), Group 2 (6-12months), Group 3 (12-24months) and Group 4 (>24months). Samples were labeled with all data (age, sex, species, locality and date of collection).

\section{Floatation technique}

Faeces were examined microscopically by floatation technique using saturated sodium chloride solution according to MAFF (1986) and Urquhart et al., (1996).Positive samples were subjected to sporulation of their Eimeria oocysts.

\section{Sporulation of recovered Eimeria oocyst}

Positive samples were mixed with 20x their volume of $2.5 \% \mathrm{w} / \mathrm{v}$ an aqueous potassium dichromate solution, put in Petri dishes thin layers to allow oocysts to initiate sporulation process at room temperature (24 $\dot{\mathrm{c}}$ to $33 \dot{\mathrm{c}}$ ) for 7-10 days as previously recorded (Harper and Penzhorn, 1999). After sporulation, samples were stored at $4^{\circ} \mathrm{C}$ to keeping oocysts integrity
(Duszynski and Wilber, 1997). The dichromate solution was centrifuged to retrieve the concentrate oocysts is at $300 \mathrm{~g}$ for $10 \mathrm{~min}$ and discarded the supernatant (Harper and Penzhorn, 1999).

Identification of the recovered Eimeria spp. oocysts:

Measurements were made with an ocular eyepiece, calibrated with a micrometer, under a $40 \mathrm{x}$ objective. The identification of the recovered Eimeria spp. were conducted by measurements of diameter of non-sporulated and sporulated oocysts, their shape and color, sporocyst size and presence or absence of micropyle according to (MAFF,1986; Urquhart et al., 1996 and Soulsby, 1986).

\section{Statistical analysis}

Statistical analysis was performed by Chi square test.

\section{RESULTS}

The Morphological description and measurements of the recovered Eimeria spp. oocysts:

Morphological descriptions and measurements of the recovered Eimeria spp. oocysts were recorded and displayed as in (Fig. 1, 2, 3).

$\boldsymbol{E}$. ahasta was pinkish yellow, oval shape, smooth wall and dome shape polar cap over micropyle and its size ranged 31.7 x21.4 $\mu \mathrm{m}$.

E. fauri, micropyle was distinct with no polar cap, had transparent wall to brownish yellow to salmon pink, its size was 30.8x19.8 $\mu \mathrm{m}$ (25$33 \mu \mathrm{m} \times 18-24 \mu \mathrm{m})$.

E. granulosa had distinct micropyle with micropyle cap and transparent, brownish to yellowish in colour, oval shape, its size was 26x18.8 $\mu \mathrm{m}$ (20-35 x17-25 $\mu \mathrm{m})$.

E. crandalis was double wall ellipsoidal, its size was $23.8 \times 17.6 \mu \mathrm{m}(20-28 \times 15-22 \mu \mathrm{m})$, and neither micropyle nor polar cap is detected.

E. pallida was ellipsoidal, micropyle is imperceptible and no micro-cap and its size ranged $15.3 \times 12.9 \mu \mathrm{m}(12-20 \times 8-15 \mu \mathrm{m})$.

E. parva was spherical, $16.5 \times 15.7 \mu \mathrm{m}(12-22$ $\mathrm{x} 10-18 \mu \mathrm{m})$, and without micropyle or polar cap.

\section{Infection rate of Eimeria spp.}

The infection rate with Eimeria spp. in the examined sheep was 33.3\%(203 out of 610). Sheep coccidiosis was significantly affected by season $\left(\chi^{2}=43.13^{* * *}(\mathrm{P}<0.0001)\right)$. The highest infection rate was in autumn (51.5\%), followed by summer (31.3\%), while the lowest 
infection rate was in winter season (16\%), (Table 1).

The results as showing in (Table 2) recorded the infection rate of Eimeria spp. In four localities of Menoof district, Menoufia province, Egypt. The infection rate was the highest in Gizi (39.6\%), followed by Sinsaft (25.4\%) and the lowest infection rate was in Tamali (23.6\%). Locality of examined sheep affected significantly on the prevalence of Eimeria spp. in sheep $\left(\chi^{2}=14.72^{* *}\right.$ $(\mathrm{P}<0.002))$.

The prevalence of Eimeria spp. among various age groups was presented in (Table 3). Also, Age had a significant effect in infection of sheep with Eimeria spp. $\left(\chi^{2}=43.58 * * *\right.$ $(\mathrm{P}<0.0001))$. The highest infection rate is recorded in age group ranged from 6 to 12 months (60\%) followed by older age group ranged from 12-24 months (42.3\%) and those less than 6 months (29.6\%), while the lowest infection rate is recorded in sheep aged more than 24 months (18\%) (Table 3).

Table (4) showed the prevalence of Eimeria spp. in both sexes of the examined sheep. Out of 173 examined males, 41 males were infected with coccidiosis with an infection rate of (25.4\%). Females recorded higher infection rates (162 / 437; 37.07\%) than males.

Table (1)Seasonal prevalence of ovine coccidiosis in sheep in Menoof District.

\begin{tabular}{cccc}
\hline Season & $\begin{array}{c}\text { No. examined } \\
\text { sheep }\end{array}$ & $\begin{array}{c}\text { No. infected } \\
\text { sheep }\end{array}$ & $\begin{array}{c}\text { \% of } \\
\text { infection }\end{array}$ \\
\hline Winter & 119 & 19 & 16 \\
Spring & 144 & 41 & 28.5 \\
Summer & 179 & 56 & 31.3 \\
Autumn & 169 & 87 & 51.5 \\
Total & 610 & 203 & 33.3 \\
\hline Chi-square & \multicolumn{2}{c}{$\chi^{2}=43.13^{* * *}(\mathrm{P}<0.0001)$} \\
\hline
\end{tabular}

Table (2) prevalence of ovine coccidiosis in sheep in different localities of Menoof District.

\begin{tabular}{cccc}
\hline Locality & No. examined & No. infected & \% of infection \\
\hline Gizi & 197 & 78 & 39.6 \\
Tamali & 123 & 29 & 23.6 \\
Sinsaft & 126 & 32 & 25.4 \\
Barhim & 164 & 64 & 39.02 \\
Total & 610 & 203 & 33.3 \\
\hline Chi-square & \multicolumn{3}{c}{} \\
\hline
\end{tabular}

Table (3) the relationship between the prevalence of Eimeria spp. and age of the examined sheep.

\begin{tabular}{|c|c|c|c|}
\hline Age & No. examined & No. infected & $\%$ of infection \\
\hline $1^{\text {st }}$ group $<6 \mathrm{~m}^{*}$ & 368 & 109 & 29.6 \\
\hline $2^{\text {nd }}$ group 6-12 m & 90 & 54 & 60 \\
\hline $3^{\text {rd }}$ group $12-24 \mathrm{~m}$ & 52 & 22 & 42.3 \\
\hline $4^{\text {th }}$ group $>24 m$ & 100 & 18 & 18 \\
\hline Total & 610 & 203 & 33.3 \\
\hline Chi-square & \multicolumn{3}{|c|}{$\chi^{2}=43.58 * * *(\mathrm{P}<0.0001)$} \\
\hline
\end{tabular}

$*<6 \mathrm{~m}=$ less than 6 months.

Table (4) Prevalence of ovine coccidiosis by sex

\begin{tabular}{cccc}
\hline Sex & No. examined & No. infected & \% of infection \\
\hline Male & 173 & 41 & 25.4 \\
Female & 437 & 162 & 37.07 \\
Total & 610 & 203 & 33.3 \\
\hline Chi-square & & $\chi^{2}=9.98^{* *}(\mathrm{P}<0.002)$ \\
\hline
\end{tabular}




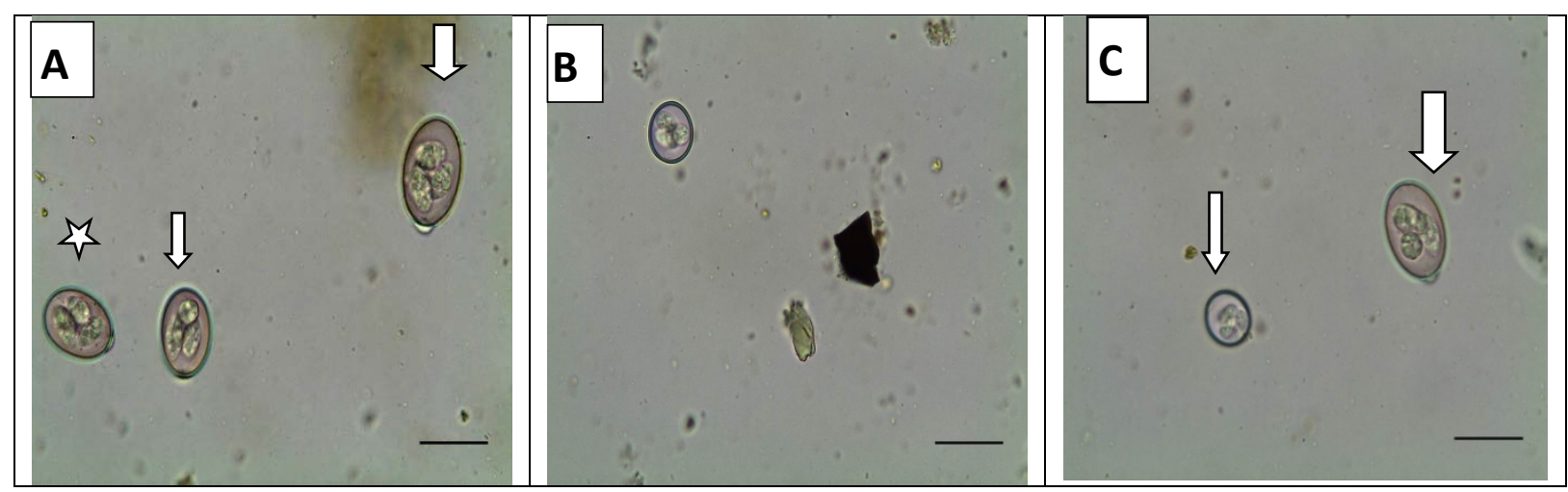

Fig.1,Eimeria spp. oocysts, A: Eimeria ahasta sporulated oocyst (thick arrow), E.crandalis sporulated oocyst (thin arrow)and E. granulosa sporulated oocyst (star); B:E.parva sporulated oocyst;C:Eimeria ahasta sporulated oocyst (thick arrow), E. pallida sporulated oocyst (thin arrow). Scale bar $=50 \mu \mathrm{m}$

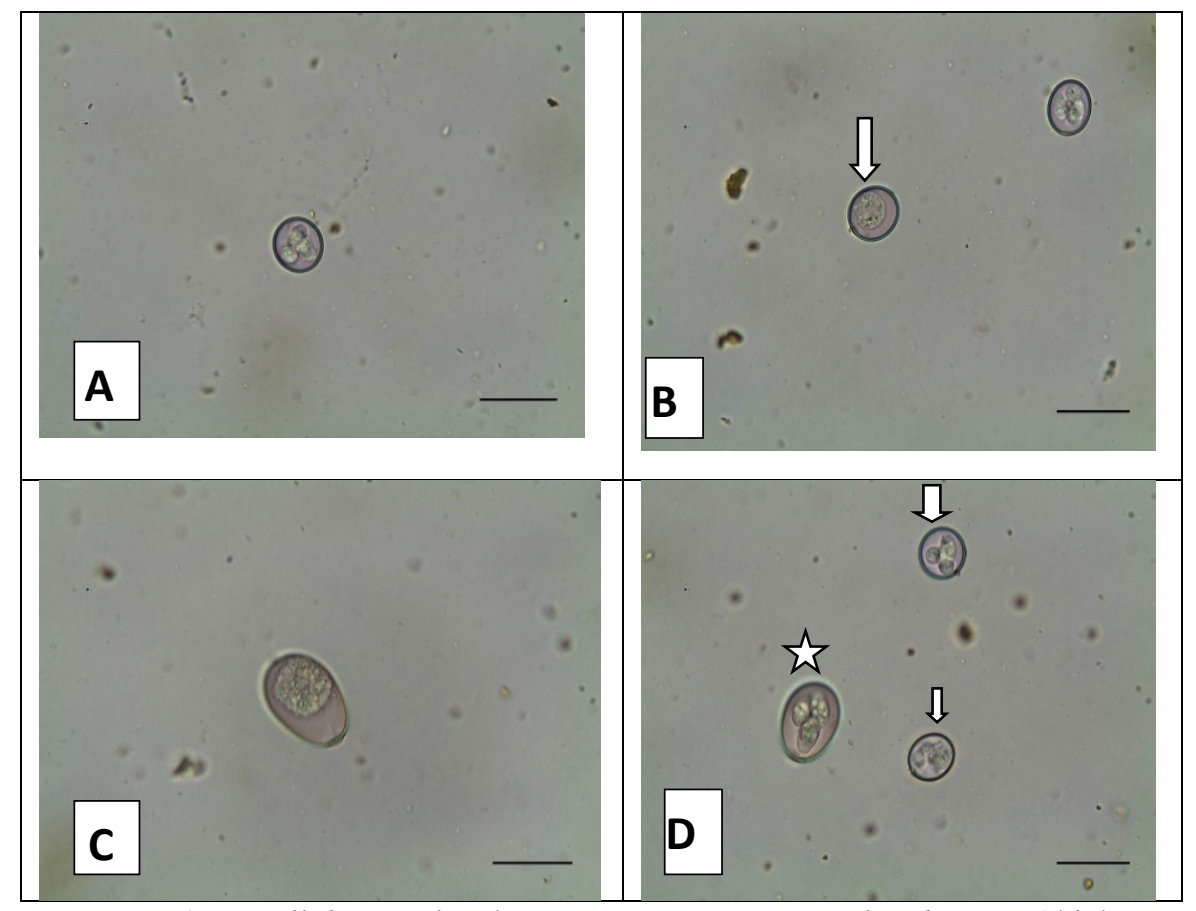

Fig. 2, Eimeria spp. oocysts, A:E. pallida sporulated oocyst; B:E. parva sporulated oocyst (thick arrow), E: pallida non sporulated oocyst (thin arrow); C:E. faurei non sporulated oocyst; D: E. parva (thick arrow), E. pallida (thin arrow) and E. fauri sporulated oocyst (star). Scale bar $=50 \mu \mathrm{m}$

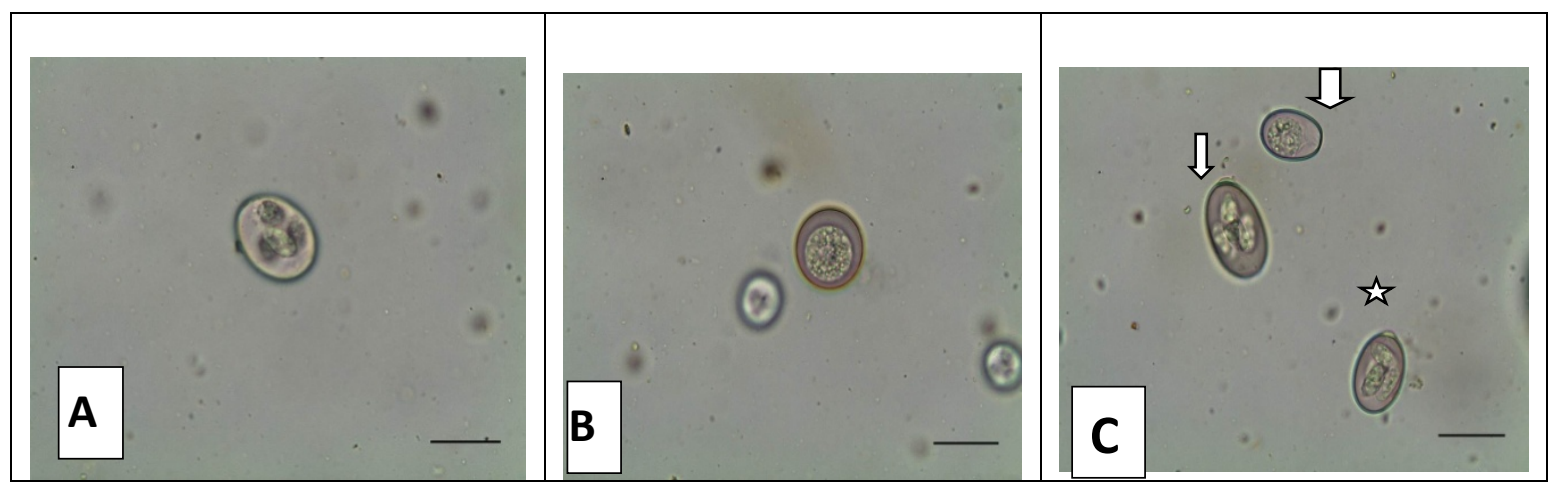

Fig. 3,Eimeria spp. oocysts, A:E. crandalis sporulated oocyst; B:E. crandalis non sporulatedoocyst; C:E. crandalis (tthick arrow), E. ahasta (thin arrow)and E. granulosa (star). Scale bar $=50 \mu \mathrm{m}$

\section{DISCUSSION}

The present study was carried out on 610 sheep to determine the prevalence of ovine coccidiosis in Menoof district, Menoufia, Egypt and associated risk factors. In present study, prevalence of Eimeria spp. in sheep was $33.3 \%$ and this rate was lower than (Ramadan et al., 2018) in Kaloubia governorate and (ElAlfy et al., 2020) in Dakahlia governorate, Egypt).

In our study, female sheep recorded higher infection rate with coccidiosis than males. This finding agrees with (Khan et al., 2011) who reported that females are more 
susceptible to coccidial infection than males. Also, (Yakhchali and Golami, 2008) founded that sex affects the infection rate of ovine coccidiosis. On the other hand, our finding disagrees with (Lakew and Seyoum, 2016; Daugschies and Najdrowski, 2005; Yakhchali and Rezaei, 2010 and Craig et al., 2007). This may be due to some factors related to sex, such as pregnancy and lactation in females make ewes to be more susceptible to infection with coccidia (Heidari et al., 2014).

Although all age-groups were infected, 6-12 months aged sheep had the highest prevalence and similar finding had been reported by (Arslan et al., 1999) in Turkey but, disagreed with (Adefolabi and Chiejina, 1987) in Southeastern Nigeria, and in Europe (Platzer et al., 2005).

The identification of species of Eimeria in sheep is based on the morphological characteristics of the unsporulated and sporulated occysts as shape, color, size, and absence or presence of micropyle and micropylar cap (Eckert et al., 1995; Levine, 1985; Levine and Ivens, 1986; Gardiner et al., 1988).

Six Eimeria spp. were recovered in the current study. The recovered Eimeria spp. in the present study were Eimeria parva, E. ahsata, E. granulosa, E. pallida, E. faurei and E. crandalis. These ovine Eimeria spp. were previously recorded from Egypt by (Ghanem and Abd El-Raof, 2005; Abou-El-Naga, 2010; Ramadan et al. 2018; El-Alfy et al., 2020). The morphological description and measurements of oocysts of recovered Eimeria spp. were reported and theses were similar to (Soulsby 1986; Ramadan et al., 2018 and ElAlfy et al., 2020).

\section{CONCLUSION}

Ovine coccidiosis was significantly affected by season, sex and age of examined sheep. Further studies should be performed on large scale to determine ovine coccidiosis risk factors.

\section{REFERENCES}

Abouzeid, N., Selim, A., El-Hady, K. (2010). Prevalence of gastrointestinal parasites infections in sheep in the Zoo garden and Sinai district and study the efficacy of anthelmintic drug in the treatment of these parasites. J. American Sci.; 6(11): 544- 551.

Abou-El-Naga, T. (2010). Prevalence of some parasitic diseases causing diarrhoea in small ruminants in northwest coastal area. In: Proceedings of the 3rd animal wealth research conference in the Middle East and North Africa, pp 14-24.

Adefolabi, T.K. and Chiejina, S. (1987). The faecal coccidial oocyst output of adult small ruminants in Nigeria. Nigerian Veterinary Journal, 16:1-6.

Arslan, M.O., Umur, S. and Kara, M. (1999). The prevalence of coccidian species in sheep in Kars province of Turkey. Tropical Animal Health and Production, 31: 161-165.

Bakunzi FR, Thwane SN, Motsei LE, Dzoma BM.2010. Diversity and seasonal occurrence of Eimeria species in a mixed flock of communally reared sheep and goats in Mafikeng in the North West Province, South Africa. J S Afr Vet Assoc.; 81(3):148-150.

Bkheet, A.A., Fadly, R.S., Elhoffy, H.R. (2010). Studies on some bacterial and parasitic causes of lamb diarrhea in Behaira province and the subsequent biochemical changes. Assuit Vet. Med. J. 56 (127).

Boshra, M.A. (1994). Some Studies on Coccodiosis in Sheep. M.V. Sc. Faculty Vet. Med. Benha Branch, Zag. Univ.

Chartier C and Paraud C. (2012): Coccidiosis due to Eimeria in sheep and goats, a review. Small Rumin Res,(2012) ; 103(1): 84-92.

Craig BH, Pilkington JG, Kruuk LEB, Pemberton J.M., (2007) Epidemiology of parasitic protozoan infections in Soay sheep (Ovis aries L.) on St Kilda. Parasitology 134:9-21

Daugschies A, and Najdrowski M., (2005). Eimeriosis in cattle: current understanding. $\mathrm{J}$ Vet Med B; 52: 417-427.

Deniz A., (2009). Coccidiose ovina: revisão bibliográfica. Albéitar; 3: 4-11.

Duszynski D.W., Wilber P.G., (1997) A guideline for the preparation of species descriptions in the Eimeriidae. J Parasitol 83:333-336

Ecker, T. J.; Braun R.; Shirley M.W. and Coudert P., (1995) Guidelines on techniques in coccidiosis research. COST 89/820. European Commission, DGXII, pp 103-117

El-Akabawy, L.M.I.,(1993) Studies on Coccidia species infecting Sheep in Kalubia Governorate. Ph. D. Faculty Vet. Med. Benha Branch, Zag. Univ.

El-Alfy, E., Ibrahim A., Yara A., Moustafa A,,Salah A., (2020). Prevalence of Eimeria species in sheep (Ovis aries) from 
Dakahlia governorate, Egypt.Journal of Parasitic Diseases . 44: 559-573.

Elmadawy, R. S. and Elkhaiat, H. M. (2014) Efficacy of Clindamycin, Yeast (Saccharomyces cerevisiae) and ClidamycinSaccharomyces cerevisiae Combination versus Toltrazuril on Experimentally Induced Coccidiosis in Lambs. IJANS. ISSN (P). 2319-4014; ISSN (E) 2319-4022. Vol.3, Issue 5.99-110.

Foreyt, W.J. (1990) Coccidiosis and cryptosporidiosis in sheep and goats. Vet. Clin. North Am. Food Anim. Pract. 6:655-670. Gadelhaq S.M.; Arafa W.M. and Aboelhadid S.M.,(2015) Molecularcharacterization of eimeriaspecies naturally infecting Egyptian Baldi chickens. Iran J Parasitol2015;10(1):8795.

Gardiner,.CH., Fayer, R. and Dubey, J.P. (1998) An atlas of protozoan parasites in animal tissues, 2nd edn. Armed Forces Institute of Pathology, Washington DC, pp 184.

Ghanem M.M. and Abd El-Raof YM (2005) Clinical and Haemato- Biochemical studies on lamb coccidiosis and changes following amprolium and sulphadimthoxine therapy. Benha Vet Med J 16:286-299

Gregory, M.W., Catchpole, J., Nolan, A. and Herbert, N., (1989). Ovine coccidiosis: Studies on the pathogenicity of Eimeria ovinoidalis, and E. crandallis in conventionally reared lambs, including possible effects of passive immunity. Deutsche Tierartzliche Wochenschrift, 96: 287-292.

Harper, C. K. and Penzhorn, B.L., (1999) Occurrence and diversity of coccidia in indigenous, Saanen and crossbred goats in South Africa. Veterinary Parasitology, 82: 1-9. Heidari, H.; Sadeghi-Dehkordi Z.; Moayedi, R. and Gharekhani, J. (2014) Occurrence and diversity of Eimeria species in cattle in Hamedan province, Iran. Vet Med 2014; 59: 271-275.

Kaya, G., (2004) Prevalence of Eimeria species in lambs in Antakya Province. Turk J Vet Anim Sci 28:687-692.

Khan, M.N.; Rehman, T. ; Iqbal, Z.; Sajid; M.S.; Ahmad, M. and Riaz, M. (2011) Prevalence and associated risk factors of Eimeria in sheep of Punjab, Pakistan. World Acad Sci Eng Technol 5:334-338.

Koudela, B. and Bokiva, A. (1998) Coccidiosis in goats in the Czech Republic. Vet. Parasitol. 76:261-67.
Lagares, A.F.B.F (2008) Parasites de pequenos ruminantes na regiao da cova da Bara (Dissertacao). Lisboa. Faculdade de Medicma Veterinaria Universidade Tecnica de Lisboa.

Lakew, K. and Seyoum, Z., (2016). Ovine coccidiosis: prevalence and associated risk factors in and around Addis-Zemen, Northwest Ethiopia. Turk J Vet Anim Sci., 40: 645-650

Levine, N. D., (1985). Veterinary Protozoology, First Edition. Iowa State University Press, Ames, IA, USA, 414p.

Levine, N. D. and Ivens, V., (1986). The Coccidian Parasites (Protozoa, Apicomplexa) of Artiodactyla. Illinois Biological Monograph 55. Illinois University Press, Chicago, IL, USA.

MAFF, (1986) Manual of Veterinary Parasitological Techniques. Technical Bulletin No. 18, Her Majesty's Stationary Office, London, UK, Pp 67-74.

Mahmoud, H.Y.A.H.; Ali, A.O.; Ali, R.H. and Ahmed, A.E. (2018) Evaluation of Clinical status and Treatment Trails in sheep and goats infested with Eimeria species. Assuit Vet. Med. J. 64, (156):123 - 128.

Mahran, O. M. (2009) Prevalence and significance of gastrointestinal parasites in Desert sheep in the triangular area (ShalatinAbuRamaid- Halaeeb) Red sea Governorate, Egypt and Trails of treatment. Assuit Vet. Med. J., 55(120).

Majeed, Q.A.; Alazemi, M.S.; Henedi, A.A. and Tahrani, L., (2015) Study on parasites from farm animals in Kuwait. J Egypt Soc Parasitol 45:71-74

McDougald, L.R., (1979) Attempted crosstransmission of coccidian between sheep and goats and description of Eimeria ovinoidalis sp. n. J Protozool 26:109-113

Mohamaden, W.I.; Sallam, N.H. and Abouelhassan, E.M. (2018) Prevalence of Eimeria species among sheep and goats in Suez Governorate, Egypt. Int. J. Vet. Sci. Med.

Nasr, S.S.M.E.; Fayek, S.A.; Azazy, O.M.E. and Amer, O. H.,(2008) Studies on Protozoa of small Ruminants in Sharkia Province. Ph. D. Vet. Med. Sci. Zag. Univ.

Platzer, B.; Prosi, H.; Cieslicki, M. and Joachim, A. (2005) Epidemiology of Eimeria infection in an Austrian milking sheep flock and control with Diclazuril. Veterinary Parasitology, 129: 1-9. 
Ramadan, M.Y.; Elmadway, R.S.; Lashin, A. I. and ELdiarby, A. S., (2018). Prevalence of Eimeria Species in Sheep with a Special Reference to Vaccinated Pregnant Ewes for Maternal Immunity for the First Time. Benha Veterinary Medical Journal..34 (3):218-231.

Reeg, K.J.; Gauly, M.; Bauer, C.; Mertens; C., Erhardt. G. and Zahner H. (2005) Coccidial infections in housed lambs: Oocyst excretion, antibody levels and genetic influences on the infection. Vet Parasitol 2005; 127(3-4): 209219.

Soulsby, E. J. L., (1986) Helminths, Arthropods and Protozoa of Domesticated Animals. Seventh Edition. Balliere Tindall London,UK.

Sultan, K., Elmonir, W. and Hegaz, Y.,(2016) Gastrointestinal parasites of sheep in Kafrelsheikh governorate, Egypt. Prevalence, control and public health implications. BeniSuef Uni. J. Bas. Appl. Sci. 5: 79-84.
Taylor, M.A. and Catchpole, J., (1994) Coccidiosis of ruminants: a review.Applied Parasitology, 35: 73 - 86.

Taylor, M.A., Marshall, R.N.; Marshall, J.A.; Catchpole, J., and Bartram D. (2011) Doseresponse effects of diclazuril against pathogenic species of ovine coccidia and the development of protective immunity. Vet Parasitol 2011; 178(1-2): 48-57.

Urquhart, G.M.; Armour, J.; Duncan, A.M. and Jennings, F.W., (1996) Veterinary Parasitology. 4th ed. Glasgow, UK: Blackwell Science.

Yakhchali, M. and Golami, E., (2008) Eimeria infection (Coccidia: Eimeriidae) in sheep of different age groups in Sanandaj city, Iran. Veterinarski arhiv 78:57-64

Yakhchali, M. and Rezaei, A.A., (2010) The prevalence and intensity of Eimeria spp. infection in sheep of Malayer suburb, Iran. Arch Razi Inst 65:27-32. 